\title{
熱流束振動を加えた正方容器内熱対流場の内部重力波共鳴*
}

\author{
松 村 聖 大*1, 石 田 秀 士*2, 木本 日出夫*2
}

\section{Internal Gravity Wave Resonance of Thermal Convection Fields in a Square Cavity with Heat-Flux Vibration}

\author{
Syota MATSUMURA*3, Hideshi ISHIDA and Hideo KIMOTO \\ ${ }^{* 3}$ Graduate School of Engineering Science, Osaka University, \\ 1-3 Machikaneyama, Toyonaka-shi, Osaka, 560-8531 Japan
}

\begin{abstract}
In this paper, the thermal convection field and its resonance phenomena in a square cavity with sinusoidal heat-flux vibration were numerically examined. As angular velocity $\omega$ is changed, the thermal convection field at $\operatorname{Pr}=0.71, R a=10^{6}$ is found to be classified into 5 regions and, particularly, the field has the local maximum of relative amplitude of midplane Nusselt's number at $\omega_{c}=350$, which corresponds to the angular velocity of internal gravity wave $\omega_{r}$ estimated by a theoretical equation proposed by Thorpe. This shows the local enhancement is induced by an internal gravity wave resonance. Such correspondence is observed for $R a \geq 10^{5}, R a \geq 10^{6}$ for $\operatorname{Pr}=0.71,7.1$, respectively. For the range of $R a$ we proposed a correlation equation, a function of $P r$ and $G r$ only, to estimate the resonant angular velocity.
\end{abstract}

Key Words: Numerical Analysis, Natural Convection, Square Cavity, Internal Gravity Wave, Resonance

1.

何らかの振動条件を与えた場合の密閉容器内自然 対流場の店答に関してはこれまでに数多くの研究が行 われている(1)(3)(11)，特に振動を加えた場合の共鳴現象 は熱伝達促進 ()や反応槽における層流混合の促進 (2) と 関車づけられるため工学的にも極めて重要である.

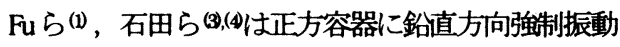
を加えた場合の熱対流場を数值解析によって調へ，加 振周波数の変化に伴って熱対流場が 5 通りに変化する ことを示すと同時に，ある種の周波数（共鳴周波数） を容器に加えた場合に伝熱面平均熱伝澾率が著しく増 加することを示した. この共鳴現象はストークス層内 部の流速から求まる対流場の循環周期と加振周期が一 致することから生じている(1).

一方, 密閉容器に熱的振動を加えた場合について も数多くの研究が行われているが，この場合には強制 振動の場合と異なり，内部重力波 ${ }^{(5)}$ ，才なわち密度成 層に伴う振動の周期と熱的振動の周期が一致する場合 に共鳴現象が起こることが知られている(た-10)．Kim ら (10は中心断面における鉿直方向平均温度勾配より Thape (のの理論式から共鳴周波数を計算し，実際の共

\footnotetext{
* 原稿受付 2005 年 2 月 3 日.

*1 学生員, 大阪大学大学院基礎工学研究科(画560-8531 豊中 市待兼山町 1-3).

*2 正員, 大阪大学大学院基礎工学研究科

E-mail : matumura@me.es.osaka-u.ac.jp
}

鳴周波数と一致することを明らかれした. しかしなが らこれらの熱的振動は, 高温壁面温度, もしくは流体 の内部発熱を周期的に変動させたものであり, 壁面で の熱流束を変動させたものは少ない(11). しかしなが ら工業的には壁面での熱流束を変動させるのが最も容 易で, これによる熱対流場の応答や共鳴現象は興味の あるところである. また，そもそもこの密閉容器槽内 部の内部重力波との共鳴現象について, その発生条件 を含め, 詳細に検討しているものは見あたらない．

そこで本研究においては正方密閉容器壁面で熱流 束振動を加えることによって生じる熱対流場を数值解 析的に検討した. まず, レイレ一数(Ra)とプラントル 数 $(P r)$ を固定し, 熱流束振動角速度 $(\omega)$ を変化させた場 合の流れ場の変化を調べ，共鳴時の流れ場の特性を明 らかにすると同時に，流れ場の分類法を提案した. 次 に共鳴角速度についても調べ, Ra Pr 変化させた場 合の共鳴角速度の変化を相関式で表すことを試み，さ らに共鳴現象が起こる限界Raについても調べた.

\section{おもな粑曷}

$$
\begin{array}{ll}
a & : \text { 加熱面の熱流束振幅 }(=0.8) \\
a_{N m} & : N u_{m} \text { の無次元振幅 } \\
C_{p} & : \text { 定圧比熱 }\left[\mathrm{Jg}^{\circ} \mathrm{C}\right] \\
G r & : \text { グラスホフ数 }\left(=g \beta \Theta \mathcal{L}^{3} / v^{2}\right) \\
G_{\theta} & : \text { 定常状態における中央温度勾配 } \\
k & : \text { 熱伝導率 }\left[\mathrm{W} / \mathrm{m}^{\circ} \mathrm{C}\right] \\
L & : \text { 代表長さ(容器の幅 }[\mathrm{m}]
\end{array}
$$




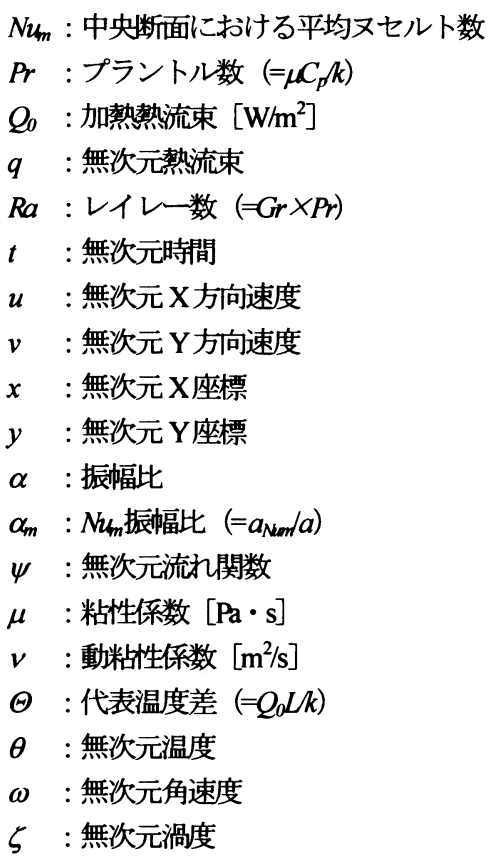

\section{2. 计 策法}

\section{1 計算モデル・萝婘式}

本研究で用いる計算モデルを図 1 に示す. 現象は 紙面に垂直方向に一様で 2 次元的であるとして, 計算 には図のような 2 次元座標を用いる. 高さ・幅共に $L$ の正方形断面容器の鈆直二面 (左右側面) の片面 (左側)を, 無次元化された時間平均熱流束 1 （実次 元で $\left.Q_{0}\right)$ を基淮として振幅 $a(=0.8)$ で正弦振動させた 無次元熱流束 $q$ を与え加熱する. 一方, 他方 (右側) を温度一定 $(\theta=0)$ の冷却壁とし，上下面を断熱壁と した. 重力は鈶直下向きに作用している. また, 壁面 は滑りなしで静止している. 初期条件として, 流体 の流速 0 , 流体の温度は泠却壁と同温とする.

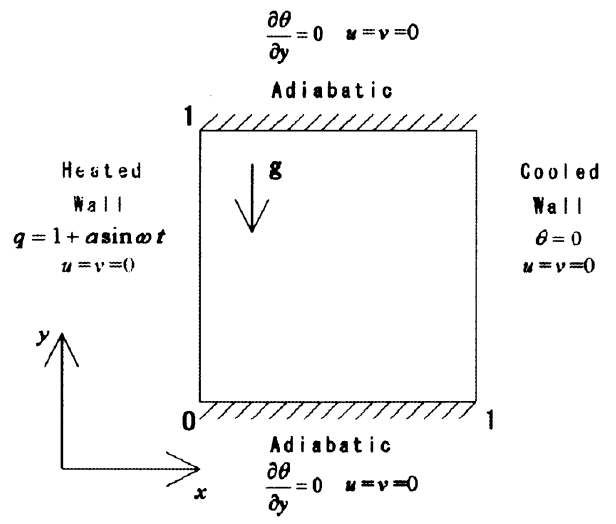

Table.1

\begin{tabular}{|c|c|c|c|}
\hline Mesh & $80 \times 80$ & $100 \times 100$ & $200 \times 200$ \\
\hline$\alpha_{m}$ & 0.933 & 0.929 & 0.926 \\
\hline
\end{tabular}

本研究では, 内部の流体の物性値は一定とし, 厳密 な基礎方程式系に対して浮力項のみの密度変化を考虑 する Bassinesq 近似を適用する. 代表長さ $L$, 動粘性 俰数 $v$ ，代表温度差 $\Theta\left(=Q_{o} L / k, k\right.$ : 熱伝導率 $)$ で無 次元化された基礎式は以下の(1)〜(3)で表される.

$$
\begin{aligned}
& \Delta \varphi=-\zeta, \quad u=\frac{\partial \varphi}{\partial y}, \quad v=-\frac{\partial \varphi}{\partial x} \\
& \frac{\partial \zeta}{\partial t}+u \frac{\partial \zeta}{\partial x}+v \frac{\partial \zeta}{\partial y}=G r \frac{\partial \theta}{\partial x}+\Delta \zeta \\
& \frac{\partial \theta}{\partial t}+u \frac{\partial \theta}{\partial x}+v \frac{\partial \theta}{\partial y}=\frac{1}{\operatorname{Pr}} \Delta \theta \cdots \cdots \cdots
\end{aligned}
$$

ただし, 式(2)(3)においてグラスホフ数 $G r$, プラン トル数 $\operatorname{Pr}$ はそれぞれ $G r=g \beta \Theta \mathbb{L}^{3} / v^{2}, \operatorname{Pr}=\mu C_{p} k$ で定義 されている. 計算の際は基磷式を時間項について前進 差分, 対流項について QUICK，拡散項について中心 差分でそれぞれ離散化した．また，熱対流場の計算の 際は計算領域を $100 \times 100$ の格子に分割し, 時間刻み $\Delta t$ を $1.0 \times 10^{-6}$ とした.

\section{2 䄱度湌付}

まず本節では本研究で行った計算の精度を検証する. 本研究では Kwak ら@ と同様 (3)式を $0 \leqq y \leqq 1$ で数值積 分することにより，振動による熱対流場の特性の変化 をよく表す物理量として中央断面平均ヌセルト数 $N u_{m}$ を以下のように定義する.

$$
N u_{m}=\left.\int_{b}^{1}\left(\operatorname{Pr} u \theta-\frac{\partial \theta}{\partial x}\right)\right|_{x=1 / 2} d y
$$

本節では $\operatorname{Ra}(=\mathrm{Gr} \times P r) ， \operatorname{Pr}$ ，無次元角速度 $\omega$ をそ れぞれ $10^{6} ， 0.71 ， 10$ に固定し，準定常状態における 中央断面での平均ヌセルト数 $N u_{m}$ の振幅 $a_{\mathrm{N} \mathrm{m} m}$ と加熱壁 熱流束振幅 $a$ との振幅比 $\alpha_{\mathrm{m}}\left(=a_{\mathrm{N} m} / a\right)$ を格子分割数, 時間刻みを変化させて求めた。

表 1 に時間刻み $\Delta t=1.0 \times 10^{-6}$ における格子分割数 80 $\times 80,100 \times 100,200 \times 200$ における $\alpha_{m}$ を示寸. 表 1 よ り格子分割数 $80 \times 80,100 \times 100$ の結果は格子分割数 $200 \times 200$ の結果に比べ相対誤差 $0.79 \%$ 以内に収まって おり, 特に格子分割数 $100 \times 100$ の結果は格子分割数 $200 \times 200$ の結果に比べ高々相対誤差 $038 \%$ である. ま た, 同条件において格子分割数 $100 \times 100$, 時間刻み $\Delta t$

Fig.1 Physical model 
$=1.0 \times 10^{-7}$ の計算を行ったが, 時間刻み $\Delta t=1.0 \times 10^{-6}$ と $\Delta t=1.0 \times 10^{-7}$ の相対誤差は高々 $0.019 \%$ であった.

本論文の計算は $\operatorname{Pr}=0.71$ において $\omega=2800$ まで, $P r=7.1$ においては $\omega=1000$ までの計算を行っており，角 速度の大きい計算を行う場合のメッシュ分割の影響に ついても考慮すべきところである. 今回の計算の場合 には既報 (3)で扱った速度境界層(ストークス層)の厚さ に加え, 温度境界層の厚さとしてこの厚さに $\operatorname{Pr}^{-1 / 2}$ を か计たものの両方がメッシュ分割の妥当性を考える上 での基準となる. Prが1より小さい場合にはストーク ス層の方が薄くなるのでこれを用いることにすると, メッシュを 100 分割する場合にはP Pr 0.71 の場合この 境界層内部に最小で約 12 個の計算セルが配置される ことになる. また $\mathrm{P}=7.1$ の場合には温度境界層内部に 最小で約 8 個のセルか配置される. 既報(3の結果によ ると振動熱対流場の計算のためには境界層内部に 7 個 のセルが存在すれば十分であるとの結果が得られてい る.
以上の結果から本研究で行った格子分割数 $100 \times$ 100 , 時間刻み $\Delta t=1.0 \times 10^{-6}$ による計算結果は十分な 精度を有しているとみなせる.

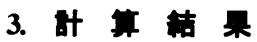

本章では熱流束振動角速度 $\omega$ を変化させた場合の 共鳴現象を含む熱対流場の変化を詳説する. ただし, 本章では $P r=0.71, R a=10^{6}$ に固定している.

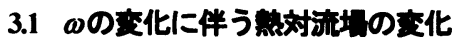

$\omega$ を変化させていくと, 熱対流場もそれに応じて 変化する. 図 2 (a) (f) に代表的な $\omega$ におおる位相 $\pi / 2$ における流れ関数を示す.これらの図からのを変化さ せると全く異なった流れ場を示していることが分かる.

$\omega=0$ での流れ関数を図 2 (a)に示しているが, これ は熱流束を変化させない場合の流れ場である.この 場合の流れ場は, 容器の中心断面と冷却壁面の中央あ たり $(x=0.8$ 付近) を渦の中心とした流れ関数の分布

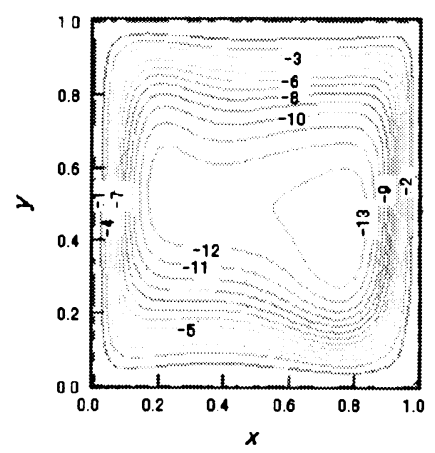

(a) $\omega=0$

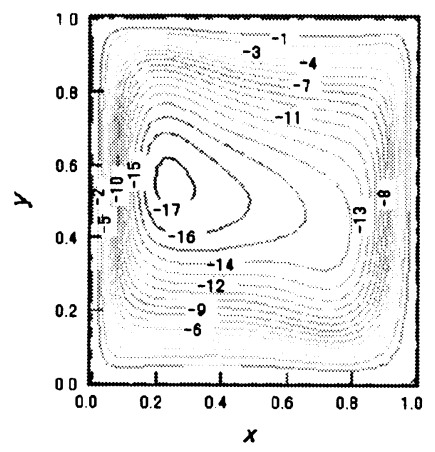

(d) $\omega=\mathbf{3 0 0}$

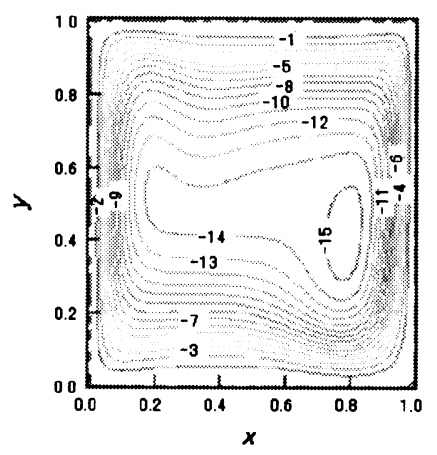

(b) $\omega=2$

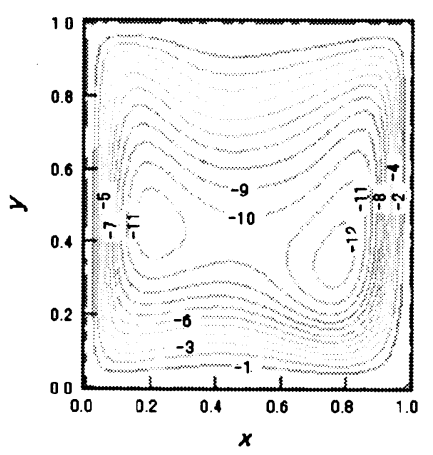

(e) $\omega=500$

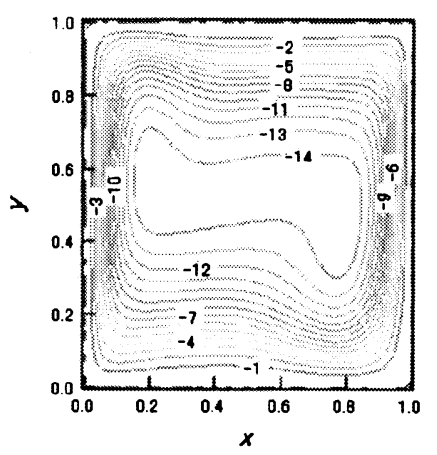

(c) $\omega=20$

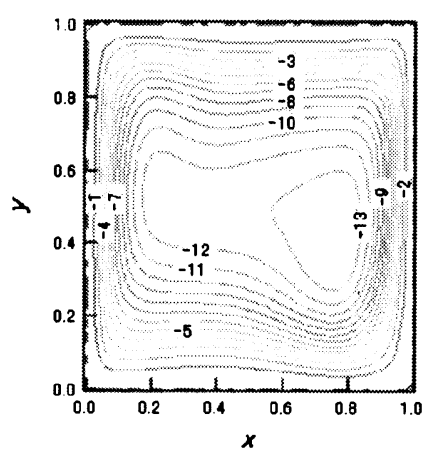

(f) $\omega=2800$

Fig,2 Stream function 
になっている.この条件では流れ場は自励振動せずに 定常状態が実現している.

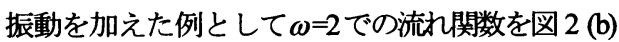
に示しているが， $\omega=0$ の場合に比へ，全体的な流れ 場は相似であるが，流れ関数の絶対值が少し大きい． つまり容器内全体の循環流量が $\omega=0$ の場合に比べて 少し大きい事を示している.

さらに振動数を上げた例として $\omega=20$ での流れ関数 を図2(c)に示しているが， $\omega=0$ の場合のように渦の 中心の位置に偏りなく, 全体の流れ場がほぼ中心対 称になっている.

次に $\omega=300$ での流れ関数を図 2 (d)に示しているが, 他のケースに比べ全く流れ場が異なっている．中央 断面よりやや左側を中心として流れ関数の絶対值か泪 2 で示した中で一番大きい渦ができており, 容器内の 循環流量が図 2 に示した中で一番大きくなっている. その結果, 壁面近傍の速度境界層も薄くなっている様 子が見て取れる. そのため, 図には示していないが, 他のケースと異なり位相が $\pi$ の周辺で非常に強い循環 流が形成されており, 後述の共鳴現象が現れている.

また $\omega=500$ での流れ関数を図 2 (e)に示しているが, これも他のケースに比べ大きく流れ場が異なってお り，中央断面の右側と左側の両方に渦ができている. また，流れ関数の絶対值は図 2 の中で一番小さく，そ の結果, 容器内の循環流量は図 2 の中で一番小さくな っている

最後に最も角速度を大きくした場合の例として $\omega=2800$ での流れ関数を図 2 (f)に示しているが，これ は $\omega=0$ の流れ場とほほ同じである.これは， $\omega$ が大き すぎるために熱流束の正弦振動の影響域は㘦熱壁のご く近傍に限られ，全体としては時間平均効果しか現れ ず，時間平均された熱流束は $\omega=0$ の場合と等しいた めと考えられる。

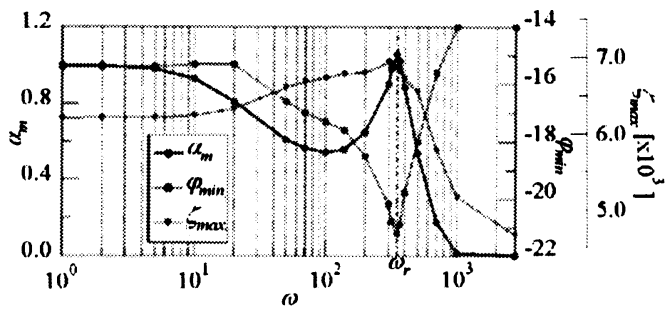

Fig3 Retative amplitude of midplane Nusselt's number, minimum stream function and maximum vorticity on the heated side wall at $P r=0.71$ and $R a=10^{6}$

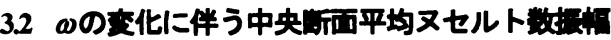 の变化}

また，図 3 に振幅比 $\alpha_{\mathrm{m}} 1$ 周期全体で見た場合の容 器内部の最小流れ関数 $\varphi_{m m}$ ならび加熱壁上の最大渦 度 $\zeta_{\text {max }}$ のグラフを示しているが, この図より， $\omega$ を 1 から増加させていくと $\omega=5$ 付近までは $\alpha_{m}$ はほぼ 1 で 変わらず, $\omega=5 \sim 100$ では $\alpha_{m}$ は减少していることが分 かる. しかし， $\omega=100$ を超えると $\alpha_{m}$ は急激に増大し， $\omega=350$ で $\alpha_{m}$ はピークになる. この $\alpha_{m}$ がピークになる 角速度を本研究では臨界角速度 $\omega_{c}$ と定義する. 図 3 によるとこの角速度において $\varphi_{m m} \zeta_{\text {max }}$ はそれぞれ最小, 最大となっている．さらに $\omega$ が増大すると $\alpha_{m}$ は急激に 減少して, $\omega>1000$ では $\alpha_{m}$ はほぼ 0 となる. 以上の結 果は前節で述べた定性的傾向に対応するものである.

図 3 で, $\omega=100 \sim 350$ で $\alpha_{m}$ が急激に増加するのは実 は内部重力波(密度成層に伴う浮力を復元力にした波 動)との共鳴によるものであり， $\omega_{c}$ は図 3 中に示され ている内部重力波の振動角速度 $\omega_{r}$ に一致寸る. これ については後述する。

\section{$3.3 \omega$ の夌化に伴う中央泞面平均ヌセルト数变动 成分の沶融の变化}

前項で考察した振幅比の変化を詳細に分析するた め, 次に本節では $N u_{m}$ の変動量の各成分とその振幅, 位相の変化を考えてみたい.

無次元温度 $\theta$, 無次元 $x$ 方向速度 $u$ 中央断面平均 ヌセルト数 $N u_{m}$ は次式のように 1 周期平均量( )とそ の周りの変動量(゙)に分割することができる.

$$
\theta=\bar{\theta}+\theta^{\prime}, \quad u=\bar{u}+u^{\prime}, \quad N u_{m}=\overline{N u_{m}}+N u_{m}{ }^{\prime}(5)
$$

(4)に(5)を代入して整理すると，

$$
\begin{aligned}
N u_{m}= & \int_{0}^{1} \operatorname{Pr} \bar{u} \bar{\theta}-\frac{\partial \bar{\theta}}{\partial x}+\operatorname{Pr} \bar{u} \theta^{\prime}+ \\
& \left.\operatorname{Pr} \bar{\theta} u^{\prime}-\frac{\partial \theta^{\prime}}{\partial x}+\operatorname{Pr} u^{\prime} \theta^{\prime}\right)\left.\right|_{x=1 / 2} d y \cdots \cdots \cdots(6)
\end{aligned}
$$

となる. 変動部分の 1 周期平均は 0 だから,

$$
\overline{N u_{m}}=\left.\int_{b}\left(\operatorname{Pr} \bar{u} \bar{\theta}-\frac{\partial \bar{\theta}}{\partial x}+\operatorname{Pr} \overline{u^{\prime} \theta^{\prime}}\right)\right|_{x=1 / 2} d y \cdots \cdot(7)
$$

となる. (5)〜(7)より

$$
\begin{aligned}
& N u_{m}{ }^{\prime}=C_{1}+C_{2}+C_{3}+C_{4} \\
& C_{1}=\left.\int_{0}^{1}\left(\operatorname{Pr} \bar{u} \theta^{\prime}\right)\right|_{x=1 / 2} d y
\end{aligned}
$$




$$
\begin{aligned}
& C_{2}=\left.\int_{0}^{1}\left(\operatorname{Pr} \bar{\theta} u^{\prime}\right)\right|_{x=1 / 2} d y \\
& C_{3}=\int_{0}^{1}\left[\operatorname{Pr}\left(u^{\prime} \theta^{\prime}-\overline{u^{\prime} \theta^{\prime}}\right)\right]_{x=1 / 2} d y \\
& C_{4}=\left.\int_{0}^{1}\left(-\frac{\partial \theta^{\prime}}{\partial x}\right)\right|_{x=1 / 2} d y
\end{aligned}
$$

と表現できる. $C_{1}, C_{2}, C_{3}, C_{4}$ が中央断面平均又セ ルト数変動量の各成分である.

$\omega$ を変化させた時の中央断面平均又セルト数変動 量 $C_{1}, C_{2}, C_{3}, C_{4}$ の振幅と加熱壁熱流束振幅 $a$ との 振幅比をそれぞれ $\alpha_{1}, \alpha_{2}, \alpha_{3}, \alpha_{4}$ とし，これらの振 幅比のグラフを図4に示す.

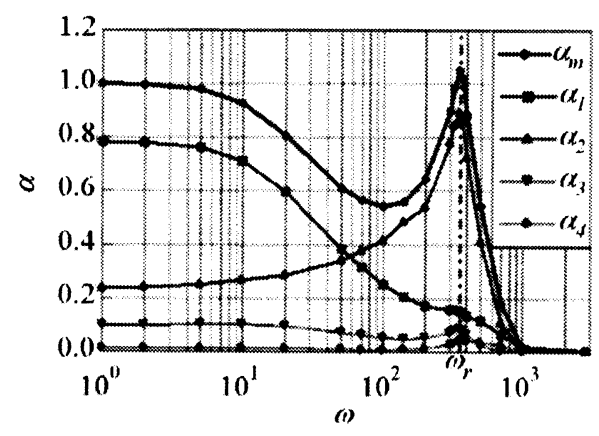

Fig.4 Relative amplitude of fluctuating components of midplane Nusselt number at $P r=0.71$ and $R a=10^{6}$

この図より，まず $\alpha_{1}$ は $\omega$ が増大するにつれ単調に 減少していることが分かる. 一方 $\alpha_{2}$ は $\omega$ を 1 から増大 させていくと単調に増大していき， $\alpha_{m}$ がピークにな

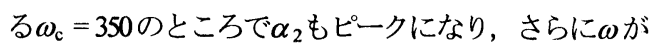

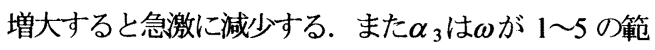

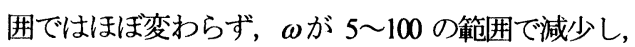
$\omega$ が $100 \sim 350$ の範用で増大し， $\omega_{\mathrm{c}}=350$ でピークにな り, $\omega>350$ では急激に減少する特性を持っており, これは $\alpha_{m}$ の特性とよく似ているが值の大きさは $\alpha_{1} や$ $\alpha_{2}$ と比較して極めて小さい. $\alpha_{4}$ の大きさは $\omega_{\mathrm{c}}=350$ 付近で $\alpha_{3}$ と同程度となるがそれ以外はほぼ 0 である.

つまり, 中央断面での平均ヌセルト数振幅は位相

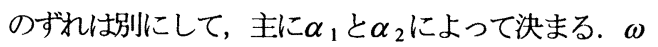

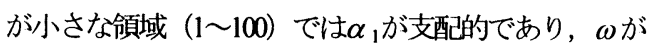
大きな領域 $(100 \sim 1000)$ ，特に共鳴現象が起こって いる $\omega$ の領域 (100〜350) では $\alpha_{2}$ が支配的である.つ まり，この領域における熱対流場は速度振幅が大きく なっており，このことは 3.1 節における $\omega=300$ の流れ 関数の絶対值 (図 2(d)参照) が他のケースに比べても つとも大きいことと対応している.
以上の考察は各成分の振動振幅の変化に関してで あるが振動位相の変化もまた重要である. 温度場, 流 れ場の変動の様子をそれぞれ $C_{1}, C_{2}$ に代表させて考 えた場合, 図には示していないが低角速度領域では加 熱壁での熱流束振動の位相は $C_{1}, C_{2}$ の位相とよく一 致しており, 角速度の増大とともに位相のずれが増大 していく.このとき $C_{1}, C_{2}$ の変動の位相のずれもま た増大していくが, 共鳴角速度付近では温度場振動 $C_{1}$ の位相と速度場振動 $C_{2}$ の位相が一致し, さらにそ れらの位相が熱流束振動の位相より約 $\pi 2$ 遅れた状態 となる. その後角速度の増大とともに $C_{1}, C_{2}$ の変動 の位相のずれが再び生じ, 同時にこれらの振動と熱流 束振動の間の位相のずれもさらに大きくなっていく.

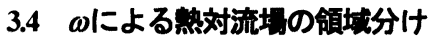

$\omega$ の変化に伴う熱対流場（3.1 節），中央断面での 平均ヌセルト数振幅（3.2 節）, ならびに中央断面で の平均ヌセルト数変動量 (3.3 節) の変化の特性から Fuら (の領域分けを参考にすると熱対流場を次の5つ の領域に分類することができる.

$$
\begin{aligned}
& \omega \leqq 5 \text { の淮静的振動対流領域（I） } \\
& 5<\omega \leqq 100 \text { の振動対流領域（II） } \\
& 100<\omega \leqq 350 \text { の共鳴振動澈対流領域（III） } \\
& 350<\omega \leqq 1000 \text { の中間対流領域 (IV) } \\
& \omega>1000 \text { の高周波振動対流領域 (V) }
\end{aligned}
$$

中央断面平均又セルト数振幅 (図 3) と各中央断面平 均ヌセルト数変動量成分の振幅（図 4) を例にとると, 準静的振動対流領域（I）では $\alpha_{m} \fallingdotseq 1$ であり, また各 変動量成分の振幅はほぼ一定である. 振動対流領域

（II）では $\omega$ が増大するにつれ $\alpha_{m}$ は減少していく. 一方 $\alpha_{1}$ は減少するが $\alpha_{2}$ は増大寸る. この領域では $\alpha_{1}$ の減少量よりも $\alpha_{2}$ の増大量が少ないので $\alpha_{m}$ は减少す ると考えられる, 共鳴振動対流領域（III）では共鳴現 象により $\omega$ が増大すると $\alpha_{m}$ は急激に増大する. この 領域でも $\alpha_{1}$ は减少し $\alpha_{2}$ は増大寸るが， $\alpha_{1}$ の減少量は 少なくなり $\alpha_{2}$ は急激に増加している. 従って, この 領域においては $\alpha_{2}$ の増大が $\alpha_{m}$ の増大に染くかかわっ ている. 中間対流領域 (IV) になると， $\omega$ が増大寸る と $\alpha_{m}$ は急激に減少している. この領域では， $\alpha_{1}$ はゆ るやかに減少するが $\alpha_{2}$ が急激に減少しており， $\alpha_{2}$ の 減少が $\alpha_{m}$ の減少に寄与している. つまり, 共鳴振動対 流領域 (III) と中間対流領域 (IV) では $\alpha_{m}$ は $\alpha_{2}$ が主 たる成分である. 高周波振動対流領域 (V) では $\alpha_{m}$ ○0であり, 各変動量成分の振幅もほぼ 0 である. 以 上の領域分けにおいて, 共鳴振動対流領域 (III) と中 
間対流領域（IV）の境界で $\alpha_{m}$ は極大になり，この境 界の $\omega=350$ が臨界角速度 $\omega_{c}$ である.

\section{4. 共惯角速 度}

\subsection{Ra，Prの変化に伴う共挐角速度の变化}

以上で述べたような $\alpha_{m}$ の増大がもし内部重力波と の共鳴によって引き起こされているならば, その臨界 角速度 $\omega_{c}$ : は内部重力波の振動角速度 $\omega_{r}$ に一致するは ずである. 密度勾配（温度勾配）が $y$ 方向に一定であ る場合には, Thapeけよると,

$$
\omega_{r}=\sqrt{\frac{\alpha^{2}}{\alpha^{2}+1} \cdot G_{\theta} \cdot G r}
$$

である.ここで $は$ はアスペクト比で, 本研究では 1 で ある. また $G_{\theta}$ は温度勾配であり，本研究で扱ってい るような密閉容器槽の場合には $G_{\theta}$ は高さ方向に一定 ではなくこの值の評価の仕方には議論のある所である が，Kim ら(10) / $\tau \omega=0$ における中央断面の $02 \leqq y \leqq 0.8$ の範用内におけ る平均温度勾配により $G_{\theta}$ を評価すると, (9)式で求ま る $\omega_{r}$ と実際の共鳴角速度 $\omega_{c}$ が一致することを報告し ている，仮にこの方法を採用するとして，Pr 0.71 で $R a=10^{5}, R a=10^{7}$ の 2 通りに変化させた場合と $P r=7.1$, $R a=10^{6}$ において， $\alpha_{m}$ の $\omega$ に対する変化と，(9)式から求 まる共鳴角速度 $\omega_{r}$ を表示したものを図 3,5 に示寸。

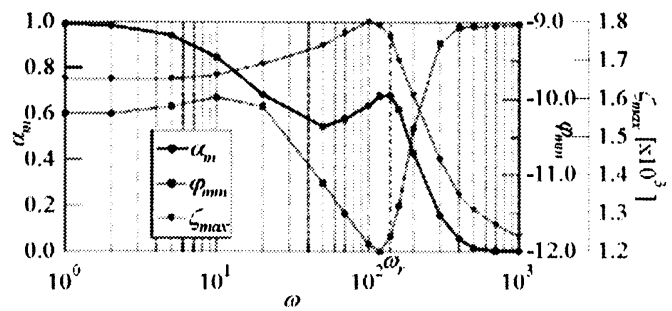

(a) $R a=10^{5}, P r=0.71$

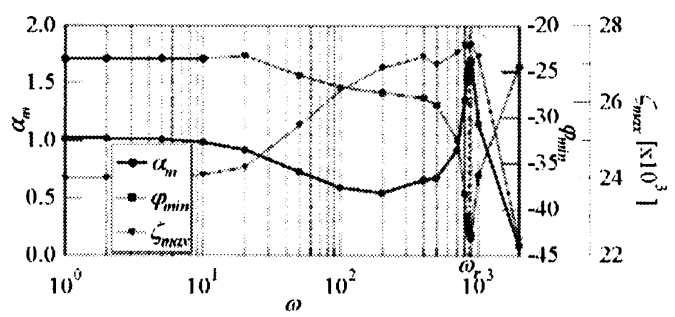

(b) $R a=10^{7}, \operatorname{Pr}=0.71$

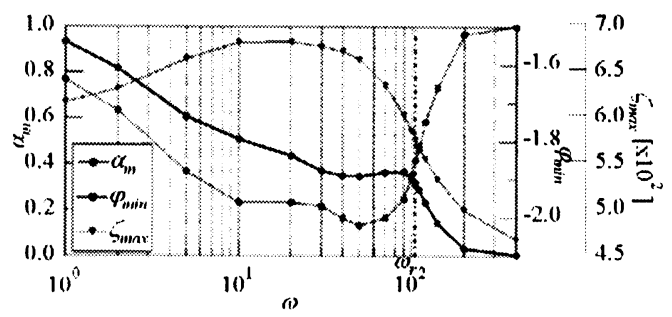

(c) $R a=10^{6}, P r=7.1$

Fig.5 Relative amplitude of midplane Nusselt number et al against angular velocity

\section{2 共响角速度相阅式の算出}

しかしながら Kim ら (10)による $G_{\theta}$ の評価法は值とし ての問題はないが $02 \leqq y \leqq 0.8$ における平均温度勾配と いう物理的根拠に乏しい方法を採用している. そこで, 本節ではこの $G_{\theta}$ の妥当な与え方を考えてみたい. 図 6にP $P=0.71, P r=7.1$ における $R a=10^{0} \sim 10^{7}$ における Kim らの方法によって求めた $G_{\theta}$ と静止状態 $(\omega=0)$ にお ける加熱壁面での平均温度 $\theta_{s}$ を示す.

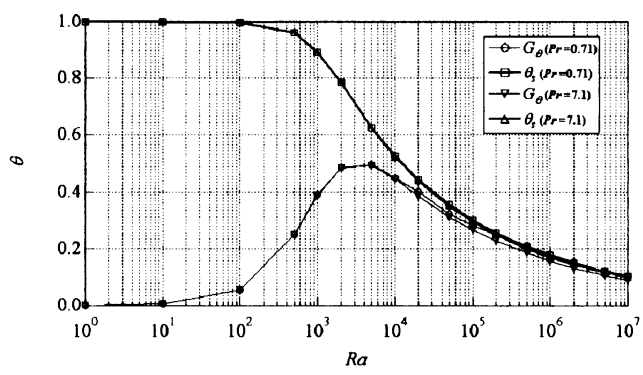

Fig.6 Temperature gradient and surface-averaged temperature on the heated side wall at $\omega=0$

この図から $G_{\theta}$ と $\theta_{s}$ は $R a=10^{4} \sim 10^{7}$ の範井で $P r=0.71$, $P r=7.1$ のいずれでもほぼ一致していることが分かる. これは, 物理的には加熱壁によって温められた流体は 容器上万に向かい，冷却壁によって冷やされた流体は 容器下方に向かうためと考えられる. 従って, (9)式の $G_{\theta}$ を $\theta_{s}$ に置き換えるほうが代表温度勾配として $G_{\theta}$ の 物理的意味がよりはっきりとする.

もちろんこのような $G_{\theta}$ が加熱壁の時間平均温度を 固定するような境界条件を用いる場合には意味を持た ず，本研究のような時間平均熱流束を固定寸るケース のみ意味を持つことは明らかである.

種々の $P r, R a$ における $\theta_{s}$ は図 7 に示しているが, この図から分かるように $\theta_{s}$ は Pr に依存せず，Raのみ 
に依存している. そこで図 7 より $\theta_{s}$ の相関式を求める と以下のようになる.

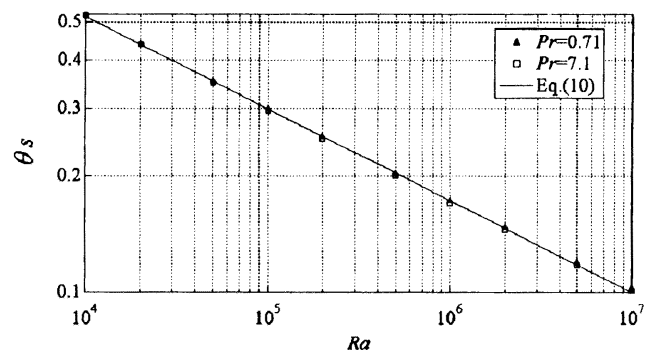

Fig.7 Surface-averaged temperature on the heated side wall at $\omega=0$

$\theta_{s}=4.63 \times R a^{-0.238}$

図7に示しているように上式で予測される $\theta_{s}$ の值は実 際の值と非常によく一致している. 従って, (9)式の $G_{\theta}$ を(10)式の $\theta_{s}$ に置き換えると次式となる.

$$
\omega_{r}=1.52 G r^{0.381} \operatorname{Pr}^{-0.119}
$$

この式から求まる $\omega_{r}$ を, 図 5 に表示した(9)式による $\omega_{r}$ と比較するとよく一致していることが確認できる. (11)式は(9)式と違って $G_{\theta}$ を含まないので $\omega_{r}$ を $P r, G r$ から求めることができ便利である.

\section{3 共㧧現象が起こる限界 $R a$}

式(11)の適用範囲は図 6より $G_{\theta}$ が $\theta_{s}$ にほぼ一致する $0.71 \leqq P r \leqq 7.1,10^{4} \leqq R a \leqq 10^{7}$ の範囲であるように思われ る. しかし実際はそうではない. 例として $R a=10^{4}, P r$ $=0.71$ において, $\omega$ を変化させた時の振幅比 $\alpha_{\mathrm{m}}$ その他 のグラフを図8に示す.

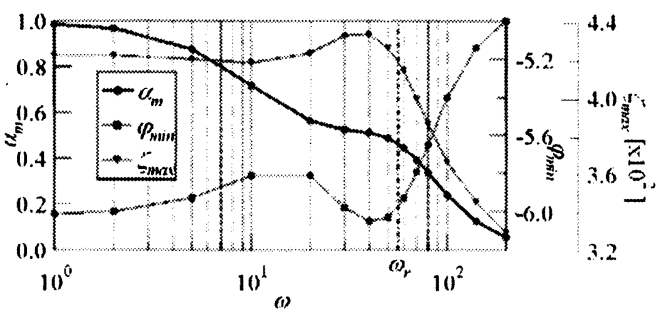

Fig.8 Relative amplitude of midplane Nusselt number et al. at $R a=10^{4}, P r=0.71$

この図から，Ra=10 ${ }^{4}, P r=0.71$ においては $\alpha_{\mathrm{m}}$ が増大す る振動対流領域亚は存在せず, $\omega_{c}$ は定義できないこ とが分かる. また $\varphi_{\text {mi }} \zeta_{\text {max }}$ をみると共鳴現象らしきも
のが $\omega=40$ で観察されるが Kim ら(10)(もしくは(11)式)で 評価される $\omega_{r}$ とは一致しない.この原因としては図 には示していないが Ra が小さいために左右の加熱・ 冷却壁の温度境界層の幅が容器の幅に比べて無視でき なくなり, 鉛直方向の内部重力波を引き起こす温度 (密度)成層と温度境界層が相互作用を起こしているた めと考えられる.このような条件下では Thapdの理 論式(9)は適用できない.したがって図 5 より式(9),(11) で評価可能な共鳴現象が現れる限界レイレ一数 Raは Pr-0.71においては $10^{5}, P r=7.1$ においては $10^{6}$ と定まる.

これ以下のレイレ一数においては温度境界層との相 互作用により，そしてまた逆に $R a か ゙ 107$ を越えると自 励振動との相互作用により共鳴現象は極めて複雑とな ると予想され, 今後の検討が必要である. さらに, 本 研究では熱流束の振動振幅 $a$ を 0.8 に固定しているが, この振幅を変えた場合の熱対流場の変化の問題も残さ れている. $a$ が小さい場合には, 熱流束振動の影響は 定常熱対流場に対する微少擾乱 (線形) とみなせるの で振幅比 $\alpha_{\mathrm{m}}$ の角速度に対する特性は変化しないと考 えられ, 実際 $a=0.4$ における $R a=10^{6}, P r=0.71$ の振幅比 $\alpha_{\mathrm{m}}$ の挙動は $a=0.8 \sigma \alpha_{\mathrm{m}}$ の挙動とほぼ一致することを確 認している. しかし， $a$ が大きくなると非線形効果が 顕著になり， $\alpha_{\mathrm{m}}$ の挙動が大きく異なってくると考え られる. また共鳴角速度については Thapeの理論式よ り, 振幅 $a$ には無関係と予想されるが, 上述の限界 $R a$ に対寸る影響はないとは断定できない.これらは 今後の課題である.

\section{5. 結論}

本研究では正方密閉容器に熱流束振動を加えるこ とによって生じる熱対流場を数值解析的に検討した. まず $R a=10^{6}, P r=0.71$ に固定し熱流束振動角速度 $\omega を$ 変 化させ，共鳴時の流れ場の特性を明らかにし，さらに $R a, \operatorname{Pr}$ を変化させた時の共鳴角速度を調べることによ り以下の結論を得た。

(1) $R a=10^{6} ， P r=0.71$ に固定し $\omega を$ 変化させると，ある 臨界角速度において非常に強い循環流が形成さ れることを流れ場から確認した．またその臨界 角速度では, 非常に強い循環流が形成されてい るので, 中央断面平均ヌセルト数変動量のうち 速度変動に基づく成分の振幅も大きく増大し, 結果として中央断面平均ヌセルト数の振幅が最 大となる.この臨界角速度は内部重力波による 振動角速度と一致し, これらの現象が内部重力 波との共鳴現象であることが確認できた. 
(2) Fu らの領域分けを参考に熱流束振動角速度によ って Ra=10，Pr=0.71 に固定した熱対流場を 5 領域 に分類した. 熱対流場, 中央断面平均ヌセルト 数振幅, 中央断面平均ヌセルト数変動量はこの 5 領域で全く違った特性を示しているので，この 分類法は妥当なものである.

(3) $R a, P r$ を変化させた時の共鳴角速度 $\omega_{r}$ はThapeに よって導出された式によってほぼ正確に求めら れることを確認した.また，その式に使われる 温度勾配は, 本研究で行ったような熱流束振動 を与える場合には $\omega=0$ における加熱壁平均温度 $\theta_{s}$ に置きかえることができ，この温度は Prに依存 せず，Raのみに依存していることを示した．以 上の結果より, 本研究では $\theta_{s}$ を $R a$ で表現する相 関式を数值計算で求めることにより， $\omega_{r}$ を $P r$, $G r$ の関数として与えることができた. この式に よってほぼ正確に共鳴角速度を求めることがで きる.

(4) Thoope が理論的に扱っている共鳴現象が起こるに は，壁面近傍における温度境界層が薄く，内部 重力波による振動を励起しうる十分な水平方向 の幅を持った密度成層が形成される必要がある. 本研究においては Pr-0.71 の場合に $R a \geqq 10^{5}$, $P r=7.1$ の場合に $R a \geqq 10^{6}$ の範囲でそのような条件 が満たされ，Thorpe の理論によって子測される共 鳴角速度で共鳴現象が起こることを現象論的に 確認した．上述の範囲は本研究で提案する共鳴 角速度の相関式のレイレ一数の適用下限を与え る.

本研究の一部は日本学術振興会科学研究費補助金若 手研究 B (No15760132)の援助を受けた. ここに記して 謝意を表する.

\section{女 部}

(1) W.S. Fu and W.J.Shieh, A study of thermal convection in an enclosure induced simultaneousty by gravity and vibration, Int. J. Heat Mass Transfer, 35(1992), 1695-1710.

（2）井上義郎, 工学としての流体混合機構の解析と混合評価, 数理解析研究所講究録, 1368(2004), 160-167.

（3）石田秀士・木本日出夫, 容器内自然対流場に打ける平均熱 伝達特性に対寸る加振の影響，機論 B, 65(1999),2413-2419.

（4）石田秀士・木本日出夫, 容器内の振動熱対流場における平 均熱伝達率の時系列データから再構築されるアトラクタの 幾何学構造, 機諞 $B, 65(1999), 2420-2425$.

(5) C.-S. Yih, Gravity waves in a stratified fluid, J. Fhid Mech, 8(1959), 481508.

(6) S. A. Thorpe, On standing intermal gravity waves of finite amplitude, $J$. Fhid Mech, 32(1968), 489-528.

(7) J. Patterson and J. Imberger, Unsteady natural convection in a rectangular cavity, J. Fhid Mech, 100(1980), 65-86.

(8) S. Paoluociand D. R. Chenoveth, Transition to chaos in a differentially heated vertical cavity,J. Fhid Mech, 201(1989),379-410.

(9) H. S. Kwak, K. Kuwahara and J. M. Hyun, Resonant enhancement of natural convection heat transfer in a square enclosure, Int. J. Heat Mass Transfer, 41(1998), 2837-2846.

(10) G. B. Kim J.M. Hyunand H. S. Kwak, Endlosed buoyant convection with intemal heat generation under oscillating sidewall temperature, $A S M E$ J. Heat Transfer, 124(2002),577-580.

(11) B. V. Antoheand J. L. Lage, Amplitude effect on convection induced by timo-periodic horizontal heating, Int.J. Heat Mass Transfer, 39(1996), 1121-1133. 